\title{
Growth of Porang Plants by Cutting the Midrib Tip and Providing Various Types of Biochar as an Intercropping in Interspace Oil Palm
}

\author{
Iqbal Effendy ${ }^{*}{ }^{1}$, Samsul Bahri ${ }^{1}$ \\ ${ }^{1}$ Study Program of Agriculture Faculty, Universitas Musi Rawas, LubukLinggau, Indonesia \\ *Corresponding author: iqbaleffendy47@yahoo.com
}

\begin{abstract}
To increase the income of smallholder oil palm farmers through the development of a polyculture pattern, which is expected to increase the LER (land Equivalent Ratio) by planting porang Plant, witch tolerant to low light intensity. This study aims to determine the effect of cutting the tip of oil palm fronds to increase light interception and to evaluate various types of biochar on the growth of porang plants, using a randomized block design (RBD) arranged in factorial with three replications. The first treatment factor is cutting the tip of the palm frond (C), namely cutting $1 \mathrm{~m}(\mathrm{C} 1)$, cutting $2 \mathrm{~m}(\mathrm{C} 2)$, and cutting $3 \mathrm{~m}(\mathrm{C} 3)$. The second treatment factor is the type of biochar (B) namely rice husk biochar (B1), corn cobs biochar (B2), and coconut shell biochar (B3). The results showed that the interaction between the treatments had a significant effect on plant height, the number of leaves, stem diameter, and dry weight of stalks. Overall, the results of this study provide hope for the development of polyculture oil palm plantations with porang plants to increase farmers' income and at the same time become an alternative source of carbohydrates considering that porang is capable of producing tubers of up to $40-50$ tons per ha.
\end{abstract}

\section{Introduction}

The porang plant (Amorphophallus Onchophillus), is one type of plant that belongs to the taro family (Araceae). In Indonesia, this plant has not been widely cultivated and only grows wild in the forest, under bamboo clumps, and on mountain slopes [1], it has the potential to be developed as an intercropping plant in palm oil with a polyculture pattern of oil palm-porang, because it can grow well in low light intensity of 50-60\% [2].

Porang plant tubers have high nutritional content such as starch content of $76.5 \%$, protein $9.20 \%$, the fiber content of $25 \%$, and fat content of $0.20 \%$ [3], have a high economic value, especially due to the substance content of "glaucoma" as an industrial raw material [4]. Porang has different regional names such as ponang (Java), crew, lorkong, labing, subeg leres, subeg bali (Madura), acung, cocoan oray, (Sunda), badur (West Nusa Tenggara) [5].

The low income of smallholder oil palm farmers in Indonesia [6,7], who have so far implemented a monoculture planting pattern, have only been able to produce 4-5 tons of FFB per ha per year, encouraging efforts to develop a poly-cropping pattern which is believed to be able to increase LER (land equivalent ratio), which in turn is expected to increase the income of smallholder oil palm farmers [8].

The development of polyculture patterns is constrained by the low light intensity under the stands $[9,10]$, besides that the ultisol soil media factor which makes up most of the smallholder oil palm plantation areas has low fertility [11] physically, chemically and biology, because it needs special treatment, including the addition of ameliorant materials such as biochar $[12,13]$. Biochar produced through the process of burning biochar raw materials in a state without or with little oxygen [14] can improve soil [15], namely through its ability to increase soil $\mathrm{pH}$, retain nutrients, increase nutrients 
available to plants, provides a good habitat for soil microbes, increases the activity of biota in the soil, and reduces pollution [16].

The raw materials commonly used in making biochar are all organic materials such as rice husks, corn cobs, coconut shells, and others. Rice husk biochar can supply the highest $\mathrm{K}$ element around $0.90 \%$, as well as the highest CEC value of $29.27 \mathrm{me} / 100 \mathrm{~g}$ [17]. Several studies have shown that rice husk biochar can improve soil and increase plant productivity. Meanwhile, biochar from the shell can increase the availability of potassium in the soil [18]. Furthermore, [19] states that the use of coconut shell biochar can increase the efficiency of using nitrogen $(\mathrm{N})$ fertilizers. It was also reported that coconut shell biochar can improve water use efficiency [20]. [21] revealed that corn cobs have low protein content $(<4.64 \%)$, high lignin content $(15.4 \%)$, and high cellulose.

The quality of biochar is determined by the manufacturing process and its raw materials. Biochar can be produced from various materials containing lignocellulose, such as wood, crop residues (, rice husks, corn cobs, coconut shells, and manure [22]. Raw materials for making biochar can also use corn cobs, corn cobs have high levels of lignin (15.4\%) and cellulose [23].

The purpose of this study was to evaluate the ability of porang plants to grow and produce tubers under oil palm stands by cutting the tips of palm fronds to increase light interception and to see the effect of giving various biochar ingredients in improving the quality of ultisol soil.

\section{Methods}

The research was conducted in the smallholder oil palm at Sukorejo Village $\left(3^{0} 8.4760\right.$ 'S dan $102^{0}$ 54.8590'E), STL Ulu Terawas Subdistrict, Musi Rawas District, South Sumatera Province, Indonesia from March to July 2020. Factorial Completely Randomized Block Design was used in this experiment which the first treatment factor is cutting the tip of the palm frond (C), namely cutting $1 \mathrm{~m}$ (C1), cutting $2 \mathrm{~m}(\mathrm{C} 2)$, and cutting $3 \mathrm{~m}(\mathrm{C} 3)$. The second treatment factor is the type of biochar (B) namely rice husk biochar (B1), corn cobs biochar (B2), and coconut shell biochar (B3). biochar dose is 10 ton ha ${ }^{-1}$ which is thoroughly given two weeks before planting. Planting plots used were $2 \times 3 \mathrm{~m}$. The porang plant seed tuber was planted with $100 \mathrm{~cm} \times 100 \mathrm{~cm}$ space. Provision of fertilizer at the time of tubers planting as $50 \mathrm{~kg}$ of urea, $100 \mathrm{~kg}$ SP-36, and $75 \mathrm{~kg}$ of KCl. Biochar characterization was done using simple pyrolysis apparatus made from a modified drum as a biochar reactor, fresh rice husk from rice milling, corn cob, and coconut shell were put in the reactor. Starting burning from the bottom of the reactor for 5 hours with the average temperature in the reactor more or less $225^{\circ} \mathrm{C}$ and after 5 hours will change to biochar. Other management practices were followed uniformly. Observations were made on plant height at the end of the study, some of the leaves, stem diameter, leaf chlorophyll contents, and weight of dry biomass and light intensity as addition data (three times during research with one-month interval). Analysis of variance was conducted manually to determine differences among treatments $(\mathrm{p}<0.05)$ and when the results showed a significant difference, it was followed by an HSD test at a 5\% level [24].

\section{Results and Discussion}

Based analysis of variance showed that there was no interaction effect to all of the parameters observed. The application of biochar had a significant effect on all of the parameters accept on the leave chlorophyll contents. whereas cutting of the front tip treatment had no significant effect on all of the parameters observed. The results of observations on the average interception of light in the gawangan due to the treatment of cutting the tip of the palm frond can be seen in Table 1 .

Table 1. Average light interception at various frond tip cutting (lux)

\begin{tabular}{cccc}
\hline $\begin{array}{c}\text { Front tip cutting } \\
\text { (c) }\end{array}$ & $\begin{array}{c}\text { Maximum light } \\
\text { interception (Lux) }\end{array}$ & $\begin{array}{c}\text { Minimum Light } \\
\text { interception (Lux) }\end{array}$ & $\begin{array}{c}\text { Everage light } \\
\text { interception (Lux) }\end{array}$ \\
\hline $\mathrm{C} 1(100 \mathrm{~cm})$ & 19,360 & 1156 & 8740 \\
$\mathrm{C} 1(200 \mathrm{~cm})$ & 30,816 & 5603 & 17683 \\
$\mathrm{C} 3(300 \mathrm{~cm})$ & 35,661 & 12586 & 20603 \\
\hline
\end{tabular}




\section{Plant height (cm)}

The results of the analysis of diversity showed that the treatment of biochar (B) had a significant effect on plant height, had no significant effect on cutting palm fronds (C), had no significant effect on the interaction of cutting edge of oil palm fronds and biochar $(\mathrm{BxC})$.

Tabel 2. The effect of Biochar Kind (B) Frond Tip Cutting (C) and its Interactions (BxC) on plant Height $(\mathrm{cm})$

\begin{tabular}{ccccc}
\hline Kind of & \multicolumn{3}{c}{ Front tip Cutting (C) } & \multirow{2}{*}{ Everage B } \\
\cline { 2 - 4 } Biochar & C1 & C2 & C3 & \\
\hline B1 & 24.00 & 23.44 & 22,33 & $\mathbf{2 3 . 2 6} \mathbf{c}$ \\
B2 & 20.56 & 21.22 & 19,78 & $\mathbf{2 0 . 5 2} \mathbf{~ a b}$ \\
B3 & 19.67 & 18.89 & 19,78 & $\mathbf{1 9 . 4 4 ~ a ~}$ \\
& $\mathbf{2 1 . 4 1}$ & $\mathbf{2 1 . 1 8}$ & $\mathbf{2 0 , 6 3}$ & \\
HSD B $\mathbf{5} \%=\mathbf{2 . 1 7}$ & & & \\
\hline
\end{tabular}

Remarks: the numbers followed by the same letters in the same column and row mean that they are not significantly different at the test level of $5 \%$.

The HSD test results in Table 2, showed that B1 treatment is significantly different from B3 and B2. B1 produced the highest plant with an average of $23.26 \mathrm{~cm}$ and B3 treatment resulted in the lowest plant height with an average of $19.44 \mathrm{~cm}$.

\section{Number of leaves (strands)}

The results of the BNJ test on the variable number of leaves in Table 3, showed that B1 treatment was significantly different from B3 but not significantly different from B2, it was known that B1 treatment produced the highest number of leaves, namely 5.15 on average and $\mathrm{B} 3$ treatment produced the lowest number of leaves, which was average - Average 4.63 strands.

Tabel 3. The effect of Biochar Kind (B) Frond Tip Cutting (C) and its Interactions (BxB) on the sum of leaves (leave)

\begin{tabular}{ccccc}
\hline \multirow{2}{*}{$\begin{array}{c}\text { Kind of } \\
\text { Biochar }\end{array}$} & \multicolumn{3}{c}{ Frond Tip Cutting (C) } & \multirow{2}{*}{ Everage B } \\
\cline { 2 - 4 } & $\mathrm{C} 1$ & $\mathrm{C} 2$ & $\mathrm{C} 3$ & $\mathbf{5 . 1 5} \mathbf{~ b}$ \\
B1 & 5.33 & 5.11 & 5.00 & $\mathbf{4 . 8 9} \mathbf{~ b}$ \\
B2 & 5.00 & 5.00 & 4.67 & $\mathbf{4 . 6 3} \mathbf{~ a}$ \\
B3 & 4.78 & 4.55 & 4.55 & \\
Everage P & & & & \\
HSD 5\% & $\mathbf{5 . 0 4}$ & $\mathbf{4 . 8 9}$ & & \\
\end{tabular}

Remarks: the numbers followed by the same letters in the same column and row mean that they are not significantly different at the test level of $5 \%$.

\section{Stem Diameter (cm)}

The results of the BNJ test in Table 4, that B1 has no significant effect on B2 and B3, it is known that B1 treatment produces the highest stem diameter with an average of $1.94 \mathrm{~cm}$ and B3 treatment produces the lowest stem diameter, namely 1.85 . The highest with an average of 1.96 and the lowest of P3B3 treatment produced leaf blades with an average of $1.79 \mathrm{~cm}$. 
Tabel 4. The effect of Biochar Kind (B) Frond Tip Cutting (C) and its Interactions (BxB) on stem diameter $(\mathrm{cm})$

\begin{tabular}{ccccc}
\hline \multirow{2}{*}{$\begin{array}{c}\text { Kind of } \\
\text { Biochar }\end{array}$} & \multicolumn{5}{c}{ Cutting } & \\
\cline { 2 - 4 } & $\mathrm{C} 1$ & $\mathrm{C} 2$ & $\mathrm{C} 3$ & Everage of B \\
\hline B1 & 1.96 & 1.96 & 1,98 & $\mathbf{1 . 9 6} \mathbf{~ b}$ \\
B2 & 1.89 & 1.90 & 1,81 & $\mathbf{1 . 8 7} \mathbf{~ a ~}$ \\
B3 & 1.86 & 1.89 & 1,79 & $\mathbf{1 . 8 5} \mathbf{~ a ~}$ \\
Everage of C & $\mathbf{1 . 9 0}$ & $\mathbf{1 . 9 1}$ & $\mathbf{1 , 8 5}$ & \\
\hline
\end{tabular}

BNJ 5\%=0,10

Remarks: the numbers followed by the same letters in the same column and row mean that they are not significantly different at the test level of $5 \%$.

\section{Dry Weight (grams)}

The results of the LSD test in Table 5 shows that the treatment of B1 is significantly different from B3 and $\mathrm{B} 2$, treatment $\mathrm{B} 1$ produces the highest dry weight, which is $11.41 \mathrm{~g}$, and treatment $\mathrm{B} 3$ produces the lowest dry weight, which is $10.00 \mathrm{~g}$.

Tabel 5. The effect of Biochar Kind (B) Frond Tip Cutting (C) and its Interactions (BxC) on Biomass dry wieght (g)

\begin{tabular}{ccccc} 
& \multicolumn{3}{c}{ Frond Tip Cutting $(\mathrm{C})$} & \\
\cline { 2 - 4 } BIOCHAR & $\mathrm{C} 1$ & $\mathrm{C} 2$ & $\mathrm{C} 3$ & Everage B \\
\hline B1 & 11.34 & 11.67 & 11.22 & $\mathbf{1 1 . 4 1} \mathbf{~ a ~}$ \\
\hline B2 & 10.89 & 10.78 & 10.78 & $\mathbf{1 0 . 8 1} \mathbf{~ a b}$ \\
\hline B3 & 10.11 & 9.89 & 10.00 & $\mathbf{1 0 . 0 0}$ b \\
\hline Everage P & $\mathbf{1 0 . 7 8}$ & $\mathbf{1 0 . 7 8}$ & $\mathbf{1 0 . 6 7}$ & \\
\hline HSD $5 \%=0,90$ & & & & \\
\hline
\end{tabular}

Remarks: the numbers followed by the same letters in the same column and row mean that they are not significantly different at the test level of $5 \%$.

Based on the results of the diversity analysis, it is known that the application of the type of biochar material has a significant and on plant height. As a soil amendment agent, biochar is widely used to solve problems in soil, increase soil CEC [25 ], provide nutrients N, P, and K [25]. Biochar maintains soil moisture so that its water holding capacity is high [26] and remediates soil contaminated with heavy metals such as $(\mathrm{Pb}, \mathrm{Cu}, \mathrm{Cd}$, and $\mathrm{Ni})$ [27]. Besides, giving biochar to the soil can also increase growth and nutrient uptake in plants [28]. Kinds of the several types of biochar that are best in increasing the growth of porang plants, namely rice husk biochar (B1). Several studies have shown that rice husk biochar can improve soil and increase plant productivity. Rice husk biochar can supply the highest $\mathrm{K}$ element around $0.90 \%$, as well as the highest CEC value of $29.27 \mathrm{me} / 100 \mathrm{~g}$ [29].

One of the variables states that biochar treatment has a significant effect. According to [30] stated that the more organic matter is applied to the soil, the increase in the ability of the soil to retain water and an increase in total nitrogen. The need for sufficient nitrogen makes overall plant growth grow well.

The results of the analysis of variance showed that the interaction between the cutting tips of oil palm fronds and biochar had no significant effect on all the variables observed. This is due to the difference in size in the treatment of palm frond tip cutting which is different, namely, $100 \mathrm{~cm}(\mathrm{P} 1)$, $200 \mathrm{~cm}$ (P2), $300 \mathrm{~cm}$ (P3), and biochar including, rice husk (B1), corn cobs (B2 ), coconut shell (B3), resulting in the two treatments together not supporting a significant increase in growth for porang plants. According to [31], that the difference in cutting the tip of the palm fronds results in a decrease 
in light intensity, this implies a decrease in the amount of photosynthate supply to the vegetative and generative organs of the porang plant so that it will affect the growth process of the porang plant which is not optimal.

The tip cutting treatment of oil palm fronds (C) had no significant effect on plant height, the number of leaves, stem diameter, chlorophyll content, and dry weight. This happens because the cutting of oil palm fronds has not been sufficient to provide light intensity so that the process of photosynthesis is disrupted resulting in not optimal growth of porang plants. According to [32], an increase in sunlight intensity is the main energy source for the photosynthesis process, so if the sunlight intensity is less then the plant is not optimal, because the photosynthetic results will be translocated throughout the plant tissue.

\section{Conclusions}

Based on the results of the research that has been carried out, it can be concluded that the $300 \mathrm{~cm}(\mathrm{P} 3)$ frond tip cutting treatment resulted in the best growth and yield of porang plants. Rice husk biochar treatment (B1) produced the best growth and production of porang plants. The combination of 100 $\mathrm{cm}$ midrib cutting treatment and rice husk biochar tends to produce the best growth and production in porang plants.

\section{Acknowledgment}

The researchers would like to thank the Unmura Institute for Research and Community Services (LPPM-UNMURA) for providing this Research Fund and facilities. Researchers also convey the same expression and high appreciation to the Head of the Laboratory of Soil and Physiology Sciences, Faculty of Agriculture, Musi Rawas University, and all parties who helped and facilitated the implementation of this research.

\section{REFERENCES}

[1] 2016 rice consumer behavior in the musi rawas district International Conference On Agribusiness Development For Human Welfare (Yogyakarta: Departement Of Agribusiness, Faculty Of Agriculture, Universitas Muhamadiyah Yogyakarta) Pp 272-8

[3] Qua, S.H. And A K. T 2010 Consumer Purchase Decisions Of Organic Food Products: An Ethnic Analysis J. Int. Consum. Mark. 22: 47-58.

[4] Kumar, P., A. Kumar S P And S R 2012 Estimation Of Demand Elasticity For Food Commodities In India K Agric. Econ. Res. Rev.24 1-14

[5] Humaidi E And Amin, Zaini N S 2015 Pola Pengeluaran Rumah Tangga Petani Karet Di Desa Binjai Kecamatan Muara Kelingi SOCIETAIV 54-8

[6] Amin Z, Andry, Humaidi E, Wahyuni N And Ningsih V Y 2020 Consumers' Perceptions And Willingness To Pay (WTP) Organic Rice J. Crit. Rev.7 48-51

[7] Sivathanu B 2015. 2015 Factors Affecting Consumer Preference Towards The Organic Food Purchases. Indian J. Sci. Technol.8 1-6

[8] Paradiba, D., M. Mappatoba And A L 2017 Faktor-Faktor Yang Mempengaruhi Permintaan Sayur Organik Di Kota Palu E-J Agribisnis5 564-571.

[9] Ameriana M 2006 Kesediaan Konsumen Membayar Premium Untuk Tomat Aman Residu Pestisida J. Hortik.16 165-74

[10] Umar H 2002 Penelitian Dalam Aplikasi Pemasaran (Jakarta: Penerbit PT Gramedia Pustaka Utama,)

[11] Pujiasmanto, B., P. Sunu, Toeranto And A I 2009 Pengaruh Macam Dan Dosis Pupuk Organik Terhadap Pertumbuhan Dan Hasil Tanaman Sambiloto (Andrographis Paniculata Ness.) J. Ilmu Tanah Dan Agroklimatologi, 6 81-90

[12] Manullang, GS, A. Rahmi Andp. A 2014 Pengaruh Jenis Dan Konsentrasi Pupuk Organik Cair Terhadap Pertumbuhan Dan Hasil Tanaman Sawi (Brassica Juncea L.) Varietas Tosakan

[13] Hartatik, W., Husnain And L W 2015 Peranan Pupuk Organik Dalam Peningkatan Produktivitas Tanah Dan Tanaman J. Sumberd. Lahan9 107-20 
[14] Suparmoko, M. F Y 2014 Ekonomika Untuk Manajer. Ekonomia Manajerial (Bogor: Penerbit In Media,)

[15] Prabowo, R. And R S 2017 Analisis Tanah Sebagai Indikator Tingkat Kesuburan Lahan Budidaya Pertanian Di Kota Semarang. J. Cendikia Eksakta2 59-64

[16] Yunus, F., O. Lambui I S 2017 Kelimpahan Mikroorganisme Tanah Pada Sistem Perkebunan Kakao (Theobroma Cacao L.) Semi-Intensif And Non-Intensif. J. Sci. Technol.6 194-205

[17] Amin Z A 2015 Bargaining Position Of Farmers In Tilapia Marketing 4th AIMI International Conference Proceeding. P ISBN: 978-602-7677-80-7. 256 - 286.

[18] Amin Z 2014 Konsentrasi Pasar Dan Posisi Tawar Petani Kelapa Sawit Dalampemasaran Tandan Buah Segar (TBS) J. Soc.3 83-8 